\title{
CLIMATE FINANCE ACTIVITIES OF THE MULTILATERAL DEVELOPMENT BANKS, EMPHASIZING THE ROLE OF THE EUROPEAN INVESTMENT BANK IN THIS REGARD
}

\author{
Zoltán Eperjesi \\ head of department, Wekerle Sándor Business School, Department of International Economics \\ 1088 Budapest, Jázmin u.8. e-mail: zoltan.eperjesi76@gmail.com
}

\begin{abstract}
Regional disparities have always been present in the history of the European Union that has become more and more significant and intense on the occasion of the continuous enlargements of the integration. The European Investment Bank (EIB) as a policy driven development bank of the European Union plays a crucial role in reducing these regional disparities and fostering the social and territorial cohesion of the union by providing funds at favourable terms. The EIB, on the path of considerable metamorphosis, is being transformed to a so called climate or green bank, having simultaneously two task to fulfil, namely to strengthen the European Union's position on the multi-polar global market and secure a just transition for those regions that are mostly hit by the measures taken for a climate-friendly and environmentally sustainable economy. All of the multilateral development banks following the parity and disparity models place great emphasis upon climate finance to contribute to sustainable economic growth, increasing employment and a heathy planet. The research covers the period of time between 2015 and 2025.
\end{abstract}

Keywords: climate bank, just transition for all, climate finance, climate adaptation and mitigation finance, renewable energy sources

\section{Introduction}

The multilateral development banks (MDBs), like the European Investment Bank, World Bank Group, Asian Development Bank presented their climate action targets for 2025, a collective commitment of climate finance of at least 65 billion USD, out of which 50 billion USD are transferred to low and middle income countries (Net 5). We can speak of 110 billion USD co-financing in this respect including private direct mobilisation of 40 billion USD.

The multilateral development banks apply two different methodologies with fundamentally different approaches to track climate change adaptation finance and climate change mitigation finance. The climate finance covers only those components, subcomponents, elements or proportions of projects that directly contribute or promote adaptation or mitigation. MDBs climate finance includes commitments from the MDBs own accounts, and from external resources channelled through and managed by the banks. Climate co-finance includes the amount of financial resources contributed by external resources including the private and public sectors.

Climate change adaptation targets to reduce the risks or vulnerabilities posed by climate change and to increase climate resilience (Net 5.). Identification of climate change adaptation finance is 
implemented as the result of a three-step process, establishing weather the project corresponds either fully or partially the MDB adaptation finance.

- "set out the project's context of vulnerability to climate change

- make an explicit statement of intent to address the vulnerability as part of the project

- articulate a clear and direct link between the vulnerability and the specific project activities" (Net 5.).

The methodology for tracking climate change adaptation finance allows a context- and location specific approach. It tracks MDB financing only for those components, elements or proportion of projects that directly contribute to or promote adaptation. This finance cannot always tracked in quantitative terms (for example operational procedures) or cannot be associated with costs. Climate adaptation finance is not intended to capture the value of an entire project or investment that may increase resilience as a result of specific adaptation activities that take place as part of the project.

Climate change mitigation reduces limits or sequesters greenhouse gas emissions (GHG) to mitigate climate change (Net 5.). However not all activities reducing GHGs are eligible to be regarded as mitigation finance. The methodology for tracking climate change mitigation finance recognises the importance of long-term structural changes, such as a shift to renewable energy technologies and the modal shift to low-carbon modes of transport. This methodology includes both greenfield and brownfield renewable energy projects as well as modal shift in projects of transport.

\section{Material and methods}

The research, that is based on the processing and synthesis of the international literature on the European Union and on the multilateral development banks' policy, is being conducted along the following hypotheses.

"The starting point of my study is that the European Union cannot simultaneously increase its competitiveness and strengthen its economic, social and territorial cohesion under the current circumstances of intensifying global economic competition.

- My second hypothesis is that the European Union's Europe 2020 Strategy put the emphasis on the increase of competitiveness, and therefore cohesion is relegated to the background.

- The further hypothesis refers to the paradigm shift that is outlined in the EU's development policy. The development policy operates on the foundation of market mechanism determined by the factors of competitiveness. The move from the bureaucratic coordination towards market coordination in the allocation of the EU funds became unambiguous. While the market coordination comes to the fore, the role of national and multilateral development banks become more important in the allocation of EU funds" (Kornai, 1990).

To be transparent and unambiguous I provide the abbreviations of the banks. WBG: World Bank Group; IsDB: Islamic Development Bank; IDBG: Inter-American Development Bank; EIB: European Development Bank; EBRD: European Bank for Reconstruction and Development; ADB: Asian Development Bank; AfDB: African Development Bank. All of these banks work on usually continental, regional level, with exception of the World Bank Group acting on a global level. The analysis of the multilateral development banks cover the period between 1995 and 2020. The study is essentially theoretical in nature; therefore it is based on secondary sources and has a multi-disciplinary character. The study's significant value added is the meticulous exploration of the sources. Apart from some handbooks and journals, the electronically available sources dominate in the study, and I have indicated their web sites in the bibliography. The used literature was written in English. 
Table 1. description of adaptation and mitigation finance

\begin{tabular}{|c|c|c|}
\hline Description & adaptation & mitigation \\
\hline $\begin{array}{l}\text { general scope of } \\
\text { qualifying activity }\end{array}$ & $\begin{array}{l}\text { the activity is typically a component } \\
\text { or element of a project, and in certain } \\
\text { circumstances an entire project, } \\
\text { contributing to resilience (including } \\
\text { socioeconomic) or adaptation to } \\
\text { climate change }\end{array}$ & $\begin{array}{l}\text { This is typically a project or component } \\
\text { thereof that avoids, reduces greenhouse gas } \\
\text { emissions, or promotes efforts to achieve } \\
\text { these goals. }\end{array}$ \\
\hline basis of tracking & $\begin{array}{l}\text { adaptation finance tracking is } \\
\text { incremental or component based, it } \\
\text { only takes into account those } \\
\text { activities that specifically addresses } \\
\text { vulnerability to climate change. } \\
\text { Eligible components are usually parts } \\
\text { of a larger project, for example water- } \\
\text { saving equipment that is part of a } \\
\text { larger capital expenditure }\end{array}$ & $\begin{array}{l}\text { Mitigation finance tracking is either project } \\
\text { or component based. Project based: if the } \\
\text { whole project is considered to be a } \\
\text { mitigation activity. For example, a typical } \\
\text { renewable energy project or a project } \\
\text { dedicated to improving the energy efficiency } \\
\text { of an existing facility. Component based: If } \\
\text { only a component of the project is a } \\
\text { mitigation activity, such as energy efficiency } \\
\text { equipment being a part of a larger capex } \\
\text { investment. }\end{array}$ \\
\hline $\begin{array}{l}\text { granular approach to } \\
\text { finance tracking }\end{array}$ & $\begin{array}{l}\text { The adaptation finance methodology } \\
\text { intends to capture only the value of } \\
\text { those activities within the project that } \\
\text { are aimed at addressing specific } \\
\text { climate vulnerabilities. Itis not } \\
\text { intended to capture the value of the } \\
\text { entire project that is made more } \\
\text { climate resilient as a consequence of } \\
\text { specific adaptation activities within } \\
\text { the project. }\end{array}$ & $\begin{array}{l}\text { Climate finance methodology intends to } \\
\text { capture only the value of the project or its } \\
\text { components that avoid, reduce, limit, or } \\
\text { promote the avoidance, reduction, limitation } \\
\text { of GHG emissions and are specified in the } \\
\text { eligible list of activities. }\end{array}$ \\
\hline scale of impact & Local, regional, national or global & Global \\
\hline $\begin{array}{l}\text { indicators to quantify } \\
\text { and compare project } \\
\text { outcomes }\end{array}$ & $\begin{array}{l}\text { Multiple indicators are needed. The } \\
\text { intended outcomes depend on the } \\
\text { nature of the project. }\end{array}$ & $\begin{array}{l}\text { All mitigation projects can be compared on } \\
\text { the basis of their direct or indirect reduction } \\
\text { of GHGs (for example: systems for } \\
\text { monitoring GHGs that lead to better use of } \\
\text { energy systems }\end{array}$ \\
\hline $\begin{array}{l}\text { qualification for } \\
\text { climate finance }\end{array}$ & $\begin{array}{l}\text { Qualification is based on a three-step } \\
\text { assessment process, taking into } \\
\text { account the climate change } \\
\text { vulnerability context, and the specific } \\
\text { project intent to reduce climate } \\
\text { vulnerabilities. }\end{array}$ & $\begin{array}{l}\text { Qualification is based on a positive listof } \\
\text { activities that qualify for mitigation finance } \\
\text { and a set of specific qualification and } \\
\text { exclusion criteria. }\end{array}$ \\
\hline $\begin{array}{c}\text { climate finance } \\
\text { tracking }\end{array}$ & $\begin{array}{l}\text { Three step assessment process, a } \\
\text { share of the project components that } \\
\text { are directly linked to the climate } \\
\text { vulnerability context and contribute to } \\
\text { climate change resilience is classified } \\
\text { as climate change adaptation finance. }\end{array}$ & $\begin{array}{l}\text { Positive list approach, financing of the } \\
\text { eligible project activities is classified as } \\
\text { climate change mitigation finance. }\end{array}$ \\
\hline
\end{tabular}

Source: Joint Report of Multilateral Development Banks (2020): Climate finance 10.p. 


\section{Analysis of the multilateral development banks concerning their climate finance activity}

When analysing the multilateral development banks financial activities it is very important to mention that we may distinguish two groups of the multilateral development banks (MDBs). The shareholders of the multilateral development banks are usually sovereign national states. I range the MDBs according to the parity and disparity models. In my view, those multilateral development banks belong to the parity model, where the owners, shareholders of the given bank and the debtors of the bank broadly cover each other. We could mention the European Investment Bank (EIB) and the Nordic Investment Bank as the best examples for this type of MDBs. The EIB as a policy driven bank of the European Union provides around $80 \%$ of its financing to the member states of the EU. The other group, working according the disparity model, covers MDBs whose shareholders and debtors are usually not at all identical. The World Bank Group, the European Bank for Reconstruction and Development, the Asian Development Bank and the African Development Bank are the best examples belonging to this group. The major shareholders of these banks, like the USA, Japan, etc. do not turn to these banks for loans and grants.

Before going into details concerning the different MDB's I provide the meaning of the abbreviations of the banks. WBG: World Bank Group; IsDB: Islamic Development Bank; IDBG: Inter-American Development Bank; EIB: European Development Bank; EBRD: European Bank for Reconstruction and Development; ADB: Asian Development Bank; AfDB: African Development Bank.

Table 2. Total MDB climate finance and net climate co-finance by economy income group (million USD)

\begin{tabular}{|l|r|r|r|r|r|r|}
\hline & \multicolumn{3}{|c|}{ MDB climate finance } & \multicolumn{2}{|c|}{ Climate co-finance } \\
\cline { 2 - 7 } & $\begin{array}{c}\text { low- and } \\
\text { middle } \\
\text { income } \\
\text { economies }\end{array}$ & $\begin{array}{c}\text { high } \\
\text { income } \\
\text { economies }\end{array}$ & total & $\begin{array}{l}\text { low- and } \\
\text { middle } \\
\text { income } \\
\text { economies }\end{array}$ & $\begin{array}{c}\text { high } \\
\text { income } \\
\text { economies }\end{array}$ & total \\
\hline Adaptation & 13936 & 1001 & 14937 & 18219 & 1210 & 19429 \\
\hline Mitigation & 27532 & 19094 & 46626 & 30124 & 53131 & 83255 \\
\hline Public & 32211 & 11508 & 43719 & 26485 & 20550 & 47035 \\
\hline Private & 9257 & 8587 & 17844 & 21857 & 33790 & 55647 \\
\hline
\end{tabular}

Source: Joint Report of Multilateral Development Banks (2020): Climate finance 8.p.

Analysing the table may establish that the MDBs provide overwhelmingly climate financing for high income economies for mitigation targets $(99,95 \%)$. The share of the private recipients of the climate finance is considerably higher in the high income economies than in the low- and middle income economies $(42,73 \%$ to $22,32 \%)$.

We can assess that all of the multilateral development banks regard the green and climate financing as a top priority. All of them strive to integrate environmental and climate protection into their financing procedures.

The table 4 shows unambiguously the fact that the European Investment Bank finances first its own member countries corresponding to the so-called "parity model". 16,42\% of the EIB climate financing was just made in different partnership countries in low- and middle income economies. It is the World 
Bank Group among the multilateral development banks belonging to the disparity model that provides the most climate financing to the low- and middle-income economies first for mitigation purposes.

Table 3. MDBs' climate commitments 2015-19 (USD billion)

\begin{tabular}{|c|c|c|c|c|c|}
\hline MDBs & 2015 & 2016 & 2017 & 2018 & 2019 \\
\hline World Bank Group & $\mathbf{1 0 , 7}$ & $\mathbf{1 1 , 5}$ & $\mathbf{1 3 , 2}$ & $\mathbf{2 1 , 3}$ & $\mathbf{1 8 , 4}$ \\
\hline IsDB & 0,0 & 0,0 & 0,0 & 0,0 & 0,5 \\
\hline IDBG & 1,7 & 2,7 & 4,3 & 5,0 & 4,4 \\
\hline EIB & $\mathbf{5 , 1}$ & $\mathbf{4 , 3}$ & $\mathbf{5 , 5}$ & $\mathbf{5 , 7}$ & $\mathbf{3 , 6}$ \\
\hline EBRD & 3,2 & 3,5 & 4,6 & 3,8 & 3,9 \\
\hline ADB & 2,9 & 4,4 & 5,2 & 4,0 & 7,1 \\
\hline AfDB & 1,4 & 1,1 & 2,3 & 3,3 & 3,6 \\
\hline Total: & 25,0 & 27,5 & 35,1 & 43,1 & 41,5 \\
\hline
\end{tabular}

Source: Joint Report of Multilateral Development Banks (2020): Climate finance 6.p.

Table 4. Total MDBs climate finance commitments for all economies where the MDBs operate 2019 (USD million)

\begin{tabular}{|l|r|r|}
\hline \multicolumn{1}{|c|}{ MDBs } & $\begin{array}{c}\text { low- and middle income } \\
\text { economies (USD million) }\end{array}$ & $\begin{array}{c}\text { high income economies } \\
\text { (USD million) }\end{array}$ \\
\hline World Bank Group & 18437 & 369 \\
\hline IsDB & 464 & 2 \\
\hline IDBG & 4417 & 18100 \\
\hline EIB & 3558 & 1079 \\
\hline EBRD & 3923 & 5 \\
\hline ADB & 7068 & 0 \\
\hline AfDB & 3600 & $\mathbf{2 0 ~ 0 9 5}$ \\
\hline Total: & $\mathbf{4 1 4 6 7}$ & $\mathbf{4 6}$ \\
\hline
\end{tabular}

Source: Joint Report of Multilateral Development Banks (2020): Climate finance 6.p.

The table representing the type of borrowers exactly demonstrates the European Investment Bank (EIB) places great emphasis on financing of the private sector in the high-income economies (38\%). The European Bank for Reconstruction and Development (EBRD) and the African Development Bank play also a crucial role in the climate financing for the private sector in the low-and middle-income economies $(33,25 \%-57,3 \%)$. The private sector has just a share of $18,32 \%$ in case of the World Bank Group's climate financing.

It is unambiguous that the European Investment Bank (EIB) plays the leading role of the adaptation and mitigation climate finance in the high-income economies. The other big player in this field is the European Bank for Reconstruction and Development (EBRD) providing climate financing in the developed world. 
Table 5. MDB climate finance by type of recipient or borrower, 2019 (USD million)

\begin{tabular}{|l|r|r|r|r|r|r|}
\hline \multirow{3}{*}{ MDBs } & \multicolumn{2}{|c|}{$\begin{array}{c}\text { for low- and middle-income } \\
\text { economies (USD million) }\end{array}$} & \multicolumn{2}{c|}{$\begin{array}{c}\text { for high-income economies } \\
\text { (USD million) }\end{array}$} & \multicolumn{2}{c|}{$\begin{array}{c}\text { total climate finance } \\
\text { (USD million) }\end{array}$} \\
\cline { 2 - 8 } & \multicolumn{1}{c|}{ private } & \multicolumn{1}{c|}{ public } & \multicolumn{1}{c|}{ private } & \multicolumn{1}{c|}{ public } & \multicolumn{1}{c|}{ private } & \multicolumn{1}{c|}{ public } \\
\hline AfDB & 1197 & 2403 & 0 & 0 & 1197 & 2403 \\
\hline ADB & 504 & 6564 & 0 & 5 & 504 & 6569 \\
\hline EBRD & 2252 & 1672 & 1077 & 2 & 3329 & 1674 \\
\hline EIB & 927 & 2631 & 6899 & 11201 & 7826 & 13832 \\
\hline IDBG & 1000 & 3418 & 348 & 193 & 1348 & 3611 \\
\hline IsDB & 0 & 464 & 0 & 2 & 0 & 466 \\
\hline WBG & 3378 & 15059 & 263 & 105 & 3641 & 15164 \\
\hline Total & $\mathbf{9 2 5 8}$ & $\mathbf{3 2 ~ 2 1 1}$ & $\mathbf{8 5 8 7}$ & $\mathbf{1 1 5 0 8}$ & $\mathbf{1 7 ~ 8 4 5}$ & $\mathbf{4 3 7 1 9}$ \\
\hline
\end{tabular}

Source: Joint Report of Multilateral Development Banks (2020): Climate finance 13.p.

Table 6. Total MDB climate finance by type of recipient or borrower, 2019 (in USD million)

\begin{tabular}{|c|c|c|c|c|c|c|c|c|c|}
\hline \multirow[b]{2}{*}{ MDBs } & \multicolumn{3}{|c|}{$\begin{array}{l}\text { for low- and middle-income } \\
\text { economies (USD million) }\end{array}$} & \multicolumn{3}{|c|}{$\begin{array}{l}\text { for high-income economies } \\
\text { (USD million) }\end{array}$} & \multicolumn{3}{|c|}{$\begin{array}{l}\text { total climate finance (USD } \\
\text { million) }\end{array}$} \\
\hline & $\begin{array}{c}\text { adaptati } \\
\text { on } \\
\text { finance }\end{array}$ & $\begin{array}{c}\text { mitigatio } \\
n \\
\text { finance }\end{array}$ & $\begin{array}{c}\text { MDB } \\
\text { climat } \\
e \\
\text { financ } \\
e \\
\end{array}$ & $\begin{array}{c}\text { adaptati } \\
\text { on } \\
\text { finance }\end{array}$ & $\begin{array}{c}\text { mitigatio } \\
\mathbf{n} \\
\text { finance }\end{array}$ & \begin{tabular}{|c}
$\begin{array}{c}\text { MDB } \\
\text { climat } \\
\text { e } \\
\text { financ } \\
\text { e }\end{array}$ \\
\end{tabular} & $\begin{array}{c}\text { adaptati } \\
\text { on } \\
\text { finance }\end{array}$ & $\begin{array}{c}\text { mitigatio } \\
\mathbf{n} \\
\text { finance }\end{array}$ & \begin{tabular}{|c} 
MDB \\
climat \\
$e$ \\
financ \\
$e$ \\
\end{tabular} \\
\hline AfDB & 2016 & 1584 & 3600 & 0 & 0 & 0 & 2016 & 1584 & 3600 \\
\hline $\mathrm{ADB}$ & 1531 & 5537 & 7068 & 5 & 0 & 5 & 1536 & 5537 & 7073 \\
\hline EBRD & 569 & 3354 & 3923 & 13 & 1066 & 1079 & 582 & 4420 & 5002 \\
\hline EIB & 387 & 3170 & 3558 & 584 & 17517 & $\begin{array}{c}18 \\
100 \\
\end{array}$ & 971 & 20687 & $\begin{array}{c}21 \\
658 \\
\end{array}$ \\
\hline IDBG & 1887 & 2531 & 4417 & 31 & 509 & 540 & 1918 & 3040 & 4958 \\
\hline IsDB & 217 & 247 & 464 & 1 & 1 & 2 & 218 & 248 & 466 \\
\hline WBG & 7329 & 11108 & $\begin{array}{c}18 \\
437\end{array}$ & 368 & 1 & 369 & 7697 & 11109 & $\begin{array}{c}18 \\
806\end{array}$ \\
\hline Total & 13936 & 27531 & $\begin{array}{c}41 \\
467\end{array}$ & 1002 & 19094 & $\begin{array}{c}20 \\
095\end{array}$ & 14938 & 46625 & $\begin{array}{c}61 \\
563 \\
\end{array}$ \\
\hline
\end{tabular}

Source: Joint Report of Multilateral Development Banks (2020): Climate finance $11 \mathrm{p}$

The climate financing of the MDBs in low- and middle-income economies concentrates overwhelmingly on mitigation goals $(66,3 \%)$. The biggest player among the MDBs corresponding the disparity model, is the World Bank Group focusing on the mitigation finance in the developing world. 
It is unambiguous that the European Investment Bank (EIB) plays the leading role of the adaptation and mitigation climate finance in the high-income economies. The other big player in this field is the European Bank for Reconstruction and Development (EBRD) providing climate financing in the developed world. The climate financing of the MDBs in low- and middle-income economies concentrates overwhelmingly on mitigation goals $(66,3 \%)$. The biggest player among the MDBs corresponding the disparity model, is the World Bank Group focusing on the mitigation finance in the developing world.

Table 7. MDB climate finance by region, 2019 (USD million)

\begin{tabular}{|c|c|c|c|}
\hline Region & $\begin{array}{c}\text { for low- and } \\
\text { middle-income } \\
\text { economies (USD } \\
\text { million) } \\
\end{array}$ & $\begin{array}{l}\text { for high-income } \\
\text { economies (USD } \\
\text { million) }\end{array}$ & Total \\
\hline Central Asia & 1492 & 0 & 1492 \\
\hline East Asia and the Pacific & 6497 & 6 & 6503 \\
\hline $\mathbf{E U}$ & 322 & 18639 & 18961 \\
\hline Europe: Non EU & 4220 & 73 & 4293 \\
\hline Latin America and the Caribbean & 7226 & 659 & 7885 \\
\hline Middle East \& North Africa & 3919 & 267 & 4186 \\
\hline South Africa & 8251 & 0 & 8251 \\
\hline Sub-Saharan Africa & 7380 & 0 & 7380 \\
\hline Multi-regional & 2160 & 452 & 2612 \\
\hline Total & 41467 & 20096 & 61563 \\
\hline
\end{tabular}

Source: Joint Report of Multilateral Development Banks (2020): Climate finance $15 \mathrm{p}$

The table demonstrates that around two-third of the climate financing of the MDBs $(67,35 \%)$ are used in the developing countries of the world. The European Union's member countries use $92,74 \%$ of the funds dedicated to high-income economies. 30,27\% of the total climate finance funds are used in the EU member countries. The second region using climate finance funds is South Africa.

\section{The European Investment Bank's (EIB) climate finance activity}

The European Investment Bank was established in 1958 in Luxembourg following the Treaty of Rome, which created the European Community (EC). The EIB is the largest multilateral financial institution in the world exceeding even such better-known institutions as the World Bank and the International Monetary Fund. As a policy driven bank, the EIB always follows and adopt the long-term objectives and development strategy of the European Union (Net 1). Its task is to contribute to the balanced and steady development of the common market by financing investment projects on a non-profit-making basis. As a supranational financial institution, the EIB aims to strengthen the economic and social cohesion of the integration by financing infrastructural, educational and health care projects contributing to the reduction of regional disparities and inequalities and enhancement of competitiveness. The bank lays great emphasis on the financing of the small- and medium sized companies (SME) by using the global loan mechanism as the SMEs employ around two-third of the working population of the member 
states, so it is crucial for the EU that they can cope with the big multinational companies. To meet this challenge the bank decided to adopt the "global loan mechanism" developed by the World Bank. In this mechanism a loan is provided to a financial intermediary that in turn provides an equivalent amount of funding to their smaller clients, namely the final beneficiaries (Thomson-Bianchi, 2019). In that case the financial intermediary takes the credit risk on the operations with the final beneficiaries and is responsible for identifying the clients, appraising and approving their credit requests, disbursing the fund and monitoring the repayments. According to this target setting the EIB can be considered as the „European bank for regional development”. The EIB played a crucial role in strengthening the membercountries and regions to fight the various issues around the challenges of inequalities. Due to the continuous enlargements of the European Union in the last decades the inequalities and disparities among the member-countries have reached a concerning level. The globalisation, the world economy, getting more and more multi-polar, generated the urging need within the core-countries of the EU to foster the competitiveness of the integration neglecting somewhat the cohesion and economic catch-up of the Eastern and Southern EU member-countries. This tendency leads to fierce disputes within the EU, as the Mediterranean and former socialist Eastern European countries strive to catch up with WesternEurope but these countries are not any more willing to finance these countries during the continuously growing fierce global competition.

\subsection{Goal setting of the European Investment Bank}

The EIB's Board of Directors approved new commitments for the climate action and environmental sustainability corresponding to the needs to accelerate the transition to a low-carbon, climate-friendly and environmentally sustainable economy.

1. The EIB Group aims to support 1 trillion EUR of investment in climate action and environmental sustainability from 2021 to 2030.

2. The bank will gradually increase the share of its annual financing dedicated to climate action and environmental sustainability to $50 \%$ by 2025 and beyond.

3. All new EIB operations will be aligned with the principles and goals of the Paris Agreement by the start of 2021 (Net 2, 2020).

The EIB wants to reach that all of its financing activities align with the principles and goals of the Paris agreement and withdraw supports that are not in line with the agreement. The new commitments emphasize the intention to leave nobody behind and to support the "just transition" for the communities and regions affected by the shift to low-carbon economies and those who are most vulnerable to the negative impacts of the changing climate and have the least ability to adaption. It is to be mentioned that the bank continues to finance long-term development objectives under a wide range of other EU public policy goals aiming at cohesion, innovation, infrastructure and small and medium-sized enterprises (SMEs).

The EIB elaborated the climate bank roadmap providing an operational framework for its activities on climate action and environmental sustainability from 2021-2025. The roadmap serves as a planning tool to assist the bank achieve its new commitments and explains how the climate related activities suit within the wider context of sustainable finance and environmental and social sustainability. The roadmap consists of four main work streams as follows:

- accelerating the transition through green finance

- increasing investment

- innovation, new business models

- ensuring a just transition for all 
- territorial just transition plans

- reduce vulnerability

- building strategic coherence and accountability

- EU sustainable finance action plan

- integrated environment, climate and social policy

- internal alignment

- supporting Paris-aligned operations

- high-emitting sectors

- transition and physical risks

- counterparties (Net 2, 2020)

\subsection{The role of the EIB Group in supporting the European Green Deal}

The EIB Group, as the EU developing bank supports the long-term goals of the European Green Deal. The bank is one of the largest global financiers of climate action and environmental sustainability. EIB disposes of a wide spectrum of financial products and advisory services (Net 6, 2020).

The bank strives to support the transition of the European Union to a low carbon, climate-resilient and environmentally sustainable economy having an integrated approach inside and outside the EU that contributes to the strengthening competitiveness of the integration, to growth and cohesion. The EU's development bank can greatly use its unique position to transfer financial and technical expertise from the union's economies to the EU's partner countries globally.

Becoming a climate bank requires that the climate bank approach and status are properly reflected across all EIB policies, regulations, priorities, targets and departments.

Table 8. EIB organisational structures most impacted by EU Climate Bank process

\begin{tabular}{|l|l|}
\hline $\begin{array}{l}\text { Requirements for becoming a } \\
\text { climate bank }\end{array}$ & Parts of the EIB organisational structure \\
\hline delivering climate neutrality & $\begin{array}{l}\text { energy \& mobility; innovation and competitiveness; } \\
\text { urban and regional development; (investment } \\
\text { operations and banking) }\end{array}$ \\
\hline $\begin{array}{l}\text { delivering adaptation and } \\
\text { resilience }\end{array}$ & $\begin{array}{l}\text { risk management agribusiness and rural } \\
\text { development; water management and security; urban } \\
\text { and regional development; (investment operations and } \\
\text { banking) }\end{array}$ \\
\hline $\begin{array}{l}\text { delivering a fair and } \\
\text { prosperous society (just } \\
\text { transition) }\end{array}$ & $\begin{array}{l}\text { agribusiness and rural development; urban and } \\
\text { regional development; innovation and } \\
\text { competitiveness; energy, mobility and advisory }\end{array}$ \\
\hline $\begin{array}{l}\text { supporting Green Deal } \\
\text { diplomacy and engagement }\end{array}$ & $\begin{array}{l}\text { EIB representations outside the EU; advisory; } \\
\text { representatives on joint MDB working groups and } \\
\text { committees }\end{array}$ \\
\hline $\begin{array}{l}\text { Cross-cutting institutional } \\
\text { implications for the EIB }\end{array}$ & $\begin{array}{l}\text { Bank-wide projects and change management } \\
\text { coordination unit; advisory }\end{array}$ \\
\hline
\end{tabular}

Source: Vernoit - Sonia Dunlop - Hawkins - Orozco, 2020, The European Investment Bank:

Becoming the EU Climate Bank, 46p

https://www.eib.org/attachments/thematic/eib_group_climate_bank_roadmap_en.pdf 
The MDBs worked closely to develop a common approach to align their activities with the goals of the Paris Agreement. The alignment framework is based on six building blocks around which specific strategies for alignment can be developed (alignment with mitigation goals; adaptation and climateresilient operations; accelerated contribution to the transition through climate finance; engagement and policy development support; reporting; align internal activities) (Net 2, 2020).

Since the adaptation of the EIB Climate Strategy in 2015, the bank made significant progress on climate action. From 2012 to 2019, the EIB supported more than 150 billion EUR in climate action, including over 20 billion EUR in developing countries. The EIB has steadily increased the proportion of financing for climate action, from 25\% in 2014 to 31\% in 2019 (Net 2, 2020).

The volume of EIB Group supports to green projects, - climate action and environmental sustainability, - will reach 50\% of the total financing by 2025 (over 30 billion EUR a year) (Net 2, 2020). The bank plays in this respect a business generating and supplementary role as a catalyst, because it usually finances up to $50 \%$ of the project cost, ensuring a minimum ratio of $1: 1$. In different project finance structures, provision of equity and subordinated debt products can help to mobilize substantial additional funds of senior debt coming from commercial banks.

\subsection{The European Investment Bank's energy lending policy}

The EIB following the EU energy policy, - to provide secure, sustainable, affordable energy sources to the citizens, - financed energy infrastructure projects in the value of around 62 billion EUR between 2015 and 2019 including investments for renewable energy, energy efficiency and electricity grid projects amounting 53 billion EUR. The bank adopted a new, ambitious energy lending policy in 2019 targeting to phase out of the financing of traditional fossil fuel energy projects, including natural gas by the end of 2021 (Net 3). The EIB, working closely with the European Commission intends to support the market integration of renewable electricity projects and enhance regional cooperation. The European energy policy framework envisages an interconnection target of $15 \%$ of the installed capacity by 2030 . Besides interconnections, further investments in national electricity networks remain top priority for the next decade concerning transmission and distribution levels. The interconnection projects for 2030 are regarded as European Projects of Common Interest (PCIs). EIB lays great emphasis on the investments increasing network flexibility.

The bank provided 11,7 billion EUR lending for energy-related projects (4,6 billion EUR for energy efficiency; 4 billion EUR for renewable energy projects; 2,3 billion EUR for electricity; 685 million EUR for natural gas and 65 million EUR for district heating projects. The bank counts to be as leading renewable energy financier providing 26 billion EUR funds on this field between 2014 and 2019 (Net 3: Energy Overview, 2020).

\subsection{The Just Transition Mechanism}

This mechanism consists of three pillars as follows:

- Pillar 1: The Just Transition Fund (JTF)

- Pillar 2: The dedicated just transition scheme under InvestEU

- Pillar 3: The new public sector loan facility for additional investments co-financed by the EIB (Net 2, 2020)

The main target of the first pillar is to reduce social and economic costs of the transition to climate neutrality. The Fund will focus first of all on territories with high employment in coal, lignite, oil shale and peat production, as well as regions with greenhouse gas-intensive industries, which are likely to be 
closed down or fundamentally restructured. The economic challenges concerning these regions refer to economic diversification and transition towards low-carbon activities with substantial growth potential and the need to reskill workers so that they are furnished with the necessary new skills to be able to perform new jobs. The range of the inevitable investments is quite broad, covering small- and medium sized enterprises, research and developments, energy efficiency, renewable energy, emission reduction, digitalisation, land restoration, up- and reskilling and trainings.

The second pillar under the InvestEU is aimed at involving private investments to achieve the targets of the just transition. First of all projects in the affected regions are appreciated that have an approved territorial just transition plan. This is particularly relevant for those projects that are dealt with in the framework of the Sustainable Infrastructure window of InvestEU (transport and energy infrastructure), improving the connectivity of the affected territories.

The third pillar of the just transition mechanism involves the public sector loan facility with the EIB. The utmost aim of the third pillar is to support increased public sector investments in those territories of the EU that face serious social, environmental and economic challenges arising due to the transition process towards the union's climate targets (Net 2, 2020). This vehicle enables loans to public sector entities for the implementation of measures to facilitate the harmonised transition to climate neutrality. Supported investments cover a wide range from energy and transport infrastructure to district heating networks, energy efficiency measures, including renovations of houses. Even though the European integration is enforced more and more to strengthen its competitiveness contrary to cohesion due to the fierce competition on the global economic market, the bank tries to undertake it in a way that the economic and social transition does not evoke regions legging behind. Strategic cohesion efforts have to be made to overcome regional disparities within and between the member states that can become even worse during the transition process. It should be avoided that spatial income inequalities remain constant and the economic activities concentrate even stronger in cities causing substantial social disparities and regions lagging behind and depopulated. The first pillar of the transition mechanism, the Just Transition Fund offers a wide range of support options for the most vulnerable regions. The Fund primarily provides grants. The second pillar establishes a dedicated transition scheme under InvestEU, aiming to leverage private financing. The third pillar has been elaborated to leverage public financing. The EIB, as a multilateral development bank provide advisory and technical assistance for the regions and projects concerned.

The EIB's annual target for cohesion lending makes up around $30 \%$ of all new operations in the EU member-countries. In the period between $2015-2019$, it provided totally 84,4 billion EUR to projects in EU cohesion regions (33,4\% credit lines; $17,3 \%$ transport; $14,8 \%$ energy; 5,7\% industry; $5,4 \%$ services; $5,1 \%$ urban development; $4,4 \%$ education; $2,8 \%$ infrastructure; $2,2 \%$ agriculture, fisheries; $1,6 \%$ health). The amount of funds for cohesion targets amounted 16,13 billion EUR in 2019 (Net 4, 2020).

The EIB can only deliver its responsibilities as a climate bank if it transforms itself as an institution. The inevitable institutional changes include the following steps to be made:

- "Mainstreaming the climate bank status to be reflected across the bank's structure (sectoral strategies, transparency policy, financial intermediary standards, client engagement strategies, appraisal guidelines).

- Building essential capacities required of a climate bank to become a knowledge bank. The EIB has to expand its technical advisory capacity.

- Increase of the capitalisation: Member countries should consider providing the EIB a climatespecific capitalisation in order to fulfil its role as the EU Climate Bank" (Vernoit et al., 2020). 
Private sector financing does not flow to necessary investments without direct public finance intervention and market reforms to reduce the risks. Green banks can be seen in this respect as business generators having a supplementary role, investors of first resort, creating new markets and investigating new opportunities. Commercial banks are considerably more likely to co-finance green projects when seeing that multilateral and national banks also participate in the given project.

\section{Conclusion}

As a policy driven bank, the EIB adopts the concept of the EU's leaders to transform itself to a European Climate Bank. The EU leaders intend to achieve that the EIB becomes the forerunner among the other multilateral development banks worldwide playing a pioneer role as a green bank. The bank's metamorphosis should serve to enhance the fame and technologies of the EU contributing to the strengthening of its global role. By playing a leading role in climate protection, the EU may reach that its environmental technologies are adopted and used worldwide ensuring huge potential export markets for new European technologies, processes, patents and products. The EIB has particularly strong potential to succeed as a climate bank due to the EU policy environment, which includes the European Green Deal. As a flagship policy of the EU, the European Green Deal is simultaneously a climate, a social, and an economic project having a great impact upon the international occurrences. By paving the way to become a climate bank, the EIB should establish an adaptation strategy enabling the bank to focus resources on higher-impact projects that deliver outcomes at system level. The EIB had rather catalysing broader public finance interventions for resilience. The EIB should increase resilience efforts in its public sector lending programs and provide extended technical assistance to the public sector. It is a further target for the bank to attract private investors and channelling the way to new markets.

In case of several multilateral development banks happened that they underwent a crucial metamorphosis generated by different political issues. Let us just think on the International Bank for Reconstruction and Development (IBRD) that was established to contribute to the economic recovery of the European countries after World War II but after that it began to finance middle-income developing countries to combat poverty. A similar fundamental change and transformation can be assessed in the case of the European Bank for Reconstruction and Development (EBRD) initiated by the French President Francois Mitterrand to foster the democratic transition of the former socialist Eastern European countries to free multiparty democracies and liberal market economy. Since the majority of these Eastern European countries joined the European Union meanwhile, the bank shifted its main financing focus gradually to Central-Asian and Near-East countries. Seemingly, the European Investment Bank (EIB) intends to modify decisively its profile, structure and financing criteria, becoming a so-called climate bank. The EIB as all of the different multilateral financial institutions follows the policies and decisions of the integration that established it. The European Union has to face quite critical challenges set by the world economy getting more and more multipolar and the emerging economies. The EIB, as the development bank of the European integration is intent on performing a significant transformation in its mechanism, namely it strives to become the largest and most influential climate multilateral development bank in the world. The EU's institutions have to elaborate efficient mechanism to manage globalization. Implementing the concept by financing creditworthy European companies disposing of the potential to reach a decisive stake on the global climate and environmental technology market, means, that the European Union succeeds to play a pioneering and inevitable role in this new, knowledge-based and decisive segment, guarantying that the EU cannot be bypassed and does not fall behind in the fierce global economic competition. The EIB as a policy driven multilateral bank 
following supranational guidelines contribute in that way to the utmost important goal of the European Union, namely to the economic and social cohesion of the EU.

\section{References}

[1] Net 1: European Investment Bank (2018). A History of Europe in 6 projects. 3p, Luxembourg. https://www.eib.org/attachments/general/history_of_eu_in_6_projects_en.pdf

[2] Thomson, C., Bianchi, M. (2019). Evaluation of SME global loans in the Enlarged Union, Synthesis Report, European Investment Bank.

https://www.eib.org/fr/attachments/ev/ev_global_loans_sme_en.pdf

[3] Kornai, J. (1990). Vision and reality, market and state: New studies on the economy and society Budapest. Corvina, Hemel Hempstead and New York: Harvester-Wheatsheaf and New York: Routledge, 1990. Also in Hungarian (1989).

[4] Net 2: European Investment Bank (2020). EIB group climate bank roadmap 2021-2025. ISBN: 978-92-861-4907-8 https://www.eib.org/attachments/thematic/eib_group_climate_bank_roadmap_en.pdf

[5] Net 3: Energy overview (2020). 3p https://www.eib.org/attachments/thematic/energy_overview_2020_en.pdf

[6] Net 4: (2020). Cohesion and regional development overview. https://www.eib.org/attachments/thematic/cohesion_and_regional_development_overview_202 $0 \_$en.pdf

[7] Net 5: Joint report on multilateral development banks: Climate finance 2019. https://publications.iadb.org/publications/english/document/2019-Joint-Report-on-MultilateralDevelopment-Banks-Climate-Finance.pdf

[8] Vernoit, I. E., Dunlop, S., Hawkins, J., Orozco, D. (2020). The European Investment Bank: Becoming the EU Climate Bank, E3G, https://9tj4025ol53byww26jdkao0x-wpengine.netdnassl.com/wp-content/uploads/09_07_20_E3G-EIB-Becoming-EU-Climate-Bank-report.pdf, www.e3g.org

[9] Net 6: (2020). https://www.switchtogreen.eu/the-eu-green-deal-promoting-a-green-notablecircular-economy/ 